\title{
ECONOMIC APPRAISAL OF IRON ORE DEPOSIT IN BUTTALA, SRI LANKA: PRELIMINARY MINERAL AND CHEMICAL EVIDENCES
}

\author{
H.A.K.L. MANJULA ${ }^{1 *}$, M.K.A.Y.A. MARAMBE ${ }^{2}$, T.B.N.S. MADUGALLA ${ }^{1}$ \\ ${ }^{1}$ Department of Physical Sciences, Faculty of Applied Sciences, \\ South Eastern University of Sri Lanka \\ ${ }^{2}$ Bowling Green State University, Ohio, USA
}

*Corresponding Author: email-www.hapugoda@gmail.com

(Received $1^{\text {st }}$ December 2019; accepted $17^{\text {th }}$ February 2020)

\begin{abstract}
Iron ore deposits have greater industrial significance since they supply raw material for steel based industries and such applications are majorly based on their mineral and chemical characteristics. Therefore, initial clear understandings on mineralogy and geochemistry of these ores would be advantageous. Present study aimed to investigate the mineral and chemical composition of the iron ore deposit exposed in Buttala, Monaragala District, Sri Lanka and to assess its economic potential. Sampling was carried out systematically along the ridge of ore containing mountain and from the host rocks. Textural and weathering characteristics of the ore samples were determined in hand specimen scale. Detail mineralogy was analyzed on X-Ray Diffractrometer (XRD) analyzer while elemental characterization was performed on X-Ray Florescence (XRF) spectrometer. Spatial distributions of iron and gangue elements of the ore were mapped using the Quantum GIS software. The deposit is mostly exposed as fresh ore bodies along the ridge of mountain and is hosted in garnet biotite gneiss. As indicated by the XRD results, common minerals of the ore deposit are magnetite and hematite with minor amounts of spinel, ilmenite and goethite. Average $\mathrm{Fe}_{2} \mathrm{O}_{3}$ content of the ore deposit is 78.84 wt. \% with 55.14 wt. \% of calculated Fe content. The spatial distribution of iron is higher at the northern and southern parts of the ridge than its middle part. The resulted $\mathrm{Fe}$ content of the ore is greater than many of the other iron ore deposits in Sri Lanka and comparable to the high grade iron ore deposits found elsewhere in the world. Concentrations of common gangue constituents of $\mathrm{Al}_{2} \mathrm{O}_{3}, \mathrm{SiO}_{2}, \mathrm{TiO}_{2}$ and $\mathrm{MgO}$ are 7.54 wt. \%, 4.40 wt. $\%, 3.6$ wt. \% and 2.54 wt. \% respectively. Contents of S and P, which are considered as common deleterious elements are negligible. Therefore, the Buttala iron ore deposit is magnetite and hematite containing, high grade iron ore deposit with greater economic potential.
\end{abstract}

Keywords: Iron ores, Buttala, Economic potential, Magnetite

\section{INTRODUCTION}

Iron is one of the most useful metals in the present day world. It constitutes about $5 \%$ of the crustal materials and considered as a common rock forming element in the Earth (Kennedy, 1990; Silver, 1993; Marion, 2012; Kanellopoulos et al., 2018). In nature, iron occurs as different compounds such as oxides, carbonates, silicates and sulphides by forming many varieties of minerals (Christie and Brathwaite, 1997; Indian Bureau of Mines, 1997). Iron bearing oxide minerals and iron bearing carbonate minerals are used as source minerals for commercial scale iron mining
(Kennedy, 1990; Pilchin, 2006; Singh and Mehrotra, 2007; Dixon, 2012). Among them iron oxides are of greater importance (Brobst and Pratt, 1973; Dixon, 2012).

Natural iron deposits with satisfactory quality and quantity, which can be used to extract metallic iron under existing economical and technical conditions are called as iron ores (Roesler, 1921; Kennedy, 1990; Yellishetty and Mudd, 2014; Summerfield, 2016). Iron ores are basically mined as raw material for producing steel (Kutz, 2002; Singh and Mehrotra, 2007; 
Jorgenson, 2010), which is being applying majorly in construction field, machineries, tools, household utilities and many other material manufacturing (Brobst and Pratt, 1973; Pilchin, 2006; Kabata-Pendias and Mukherjee, 2007; Yellishetty et al., 2010; Volborth, 2012).

Many countries such as Australia, Brazil, China, India, and Russia are currently engaged in larger scale mining of iron ores (Beukes et al., 2008, Spier et al, 2008; U.S. Geological Survey, 2018). The high grade basement of Sri Lanka is also composed of several iron ore deposits (Cooray, 1984). These Sri Lankan iron ore deposits can be categorized into three broad categories viz; (i) magnetite deposits, (ii) copper-magnetite deposits and (iii) hydrated iron oxide deposits (Cooray, 1984; Herath, 1995). The deposits expose at Wilagedara and Panirendawa in Western part of the country are magnetite type deposits. The deposit occur in Seruwila in Northeastern part of the country is copper-magnetite type (Jayawardena, 1984; Fernando, 1986). Hydrated iron oxide deposits are exposed in number of localities, mainly in the Southwestern part of the country (Cooray, 1984; Jayawardana et al., 2014).

Recently an additional iron ore deposit has been discovered in Buttala in Monaragala District (Figure 1), closer to the lithotectonic boundary between Highland Complex (HC) and Vijayan Complex [VC (Senaratne et al., 2001)]. Hitherto, few studies have been carried out sporadically elaborating the ore location, general mineralogy and chemistry of the Buttala deposit (Senaratna et al., 2001; Hewatilake et al., 2013; Amarasekara et al., 2014). However, to understand the economic potential of the ore body, a detail mineralogical and chemical characterization is needed. Hence the present study aims to characterize the mineral and chemical composition of the Buttala iron ore deposit and to assess its economic potential.

\section{METHODOLOGY}

Initially, several field visits were carried out to study the extent and field relations of the iron ore deposit, and to collect samples. Ore sampling was carried out systematically along the ridge of ore containing mountain with a $5 \mathrm{~m}$ distance and another set of samples was collected from the surrounding host rocks. About $1 \mathrm{~kg}$ weight, fresh snapped ore blocks were collected from the surface exposures by considering textural and weathering characteristics of the ore and their modes of occurrences. Totally 50 ore samples covering 21 locations were collected and each was analyzed in hand specimen scale for their mineralogy and weathering conditions.

Detail mineral and chemical analyses were carried out using representative powdered fractions $(<45 \mu \mathrm{m})$ of the ore samples. The detailed mineralogical analyses were carried out on the Siemens D-5000 X-Ray Diffraction (XRD) system at the Department of Chemistry, University of Peradeniya, Sri Lanka. The system was operating at a $40 \mathrm{kV}$ and $30 \mathrm{~mA}$ under monochromated (graphite) $\mathrm{Cu} \mathrm{K} \alpha$ radiation. The XRD spectrums were obtained from $5^{\circ}$ to $80^{\circ}$ under $0.020^{\circ}$ step size and $1 \mathrm{~s}$ step time. The qualitative evaluation was carried out by the Powder Diffraction File (PDF) data base. The chemical analyses of the investigated rocks were performed on Rigaku NEX type Wavelength Dispersive X-Ray Fluorescence Spectrometer (WD-XRF) at the Gem and Jewellery Research and Training Institute in Kaduwela, Sri Lanka. International and internal reference samples were used for calibration. Fused glass discs and pressed powder tablets were used in major elements and trace elements analyses, respectively. Spatial distributions of iron and gangue elements of the ore deposit were mapped using the Quantum Geographic Information System software.

\section{RESULTS AND DISCUSSION}

\section{FIELD RELATIONS}

The Buttala iron ore deposit is exposed as a small mountain. Larger iron ore bodies with sizes from $30 \mathrm{~cm}$ up to $3 \mathrm{~m}$ are exposed majorly along the ridge of the mountain and such exposures can be traced up to an average of 500 $\mathrm{m}$ distance. Most of these are fresh, massive, black colored exposures with a metallic luster. In several locations weakly weathered porous ore bodies with dull luster are also occurred. Occurrence of ore bodies is low at the middle portion of the ridge, where the host rocks have been emerged. Exposures of the in-situ ore boulders are frequent along the ridge of the mountain and are getting lowered towards the slope of the mountain. Gravity-transported iron ore boulders can be found on the both of west 


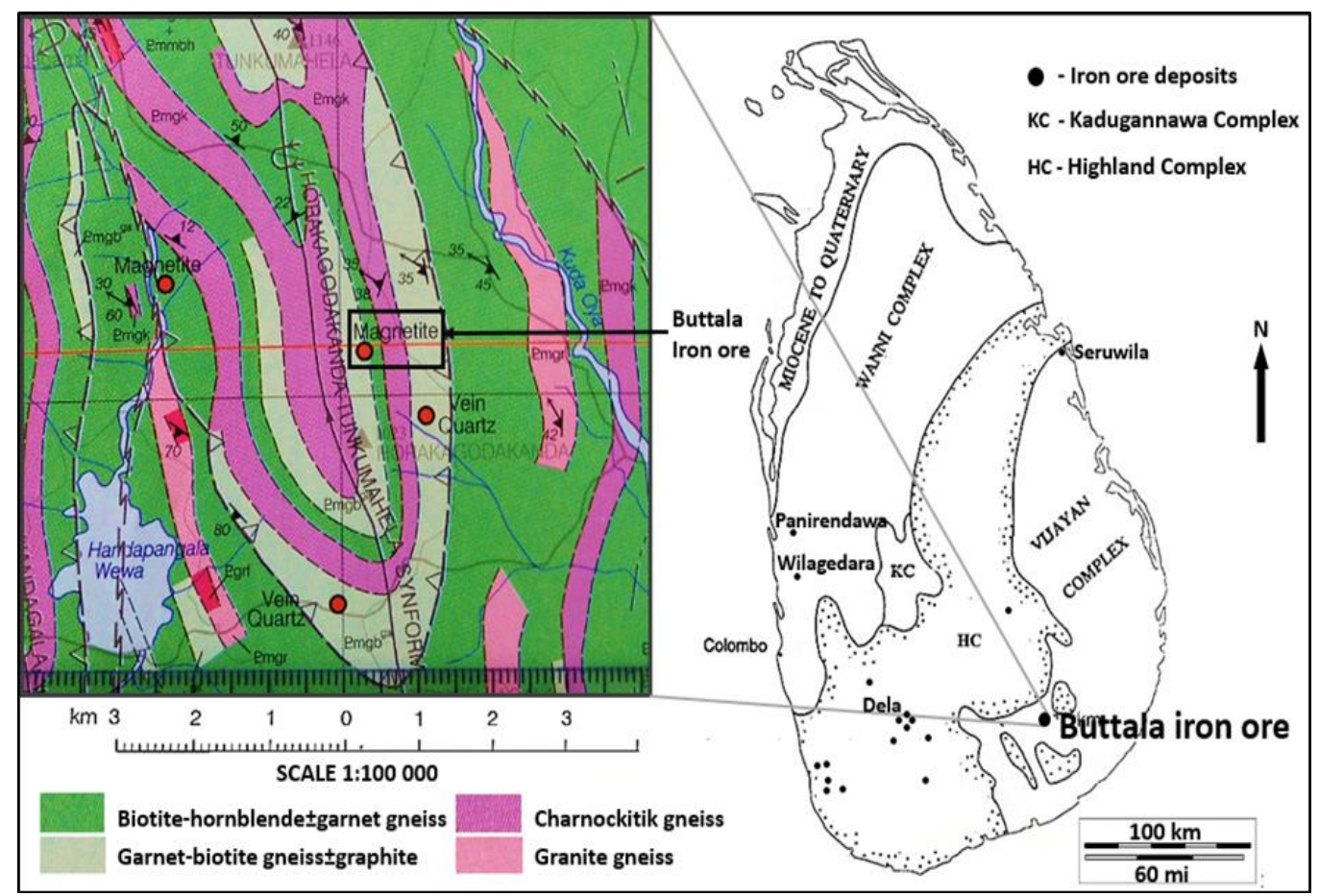

Fig. 1. A map showing geology and location of the Buttala iron-ore deposit; inset showing iron ore deposits in Sri Lanka (After Cooray, 1984).
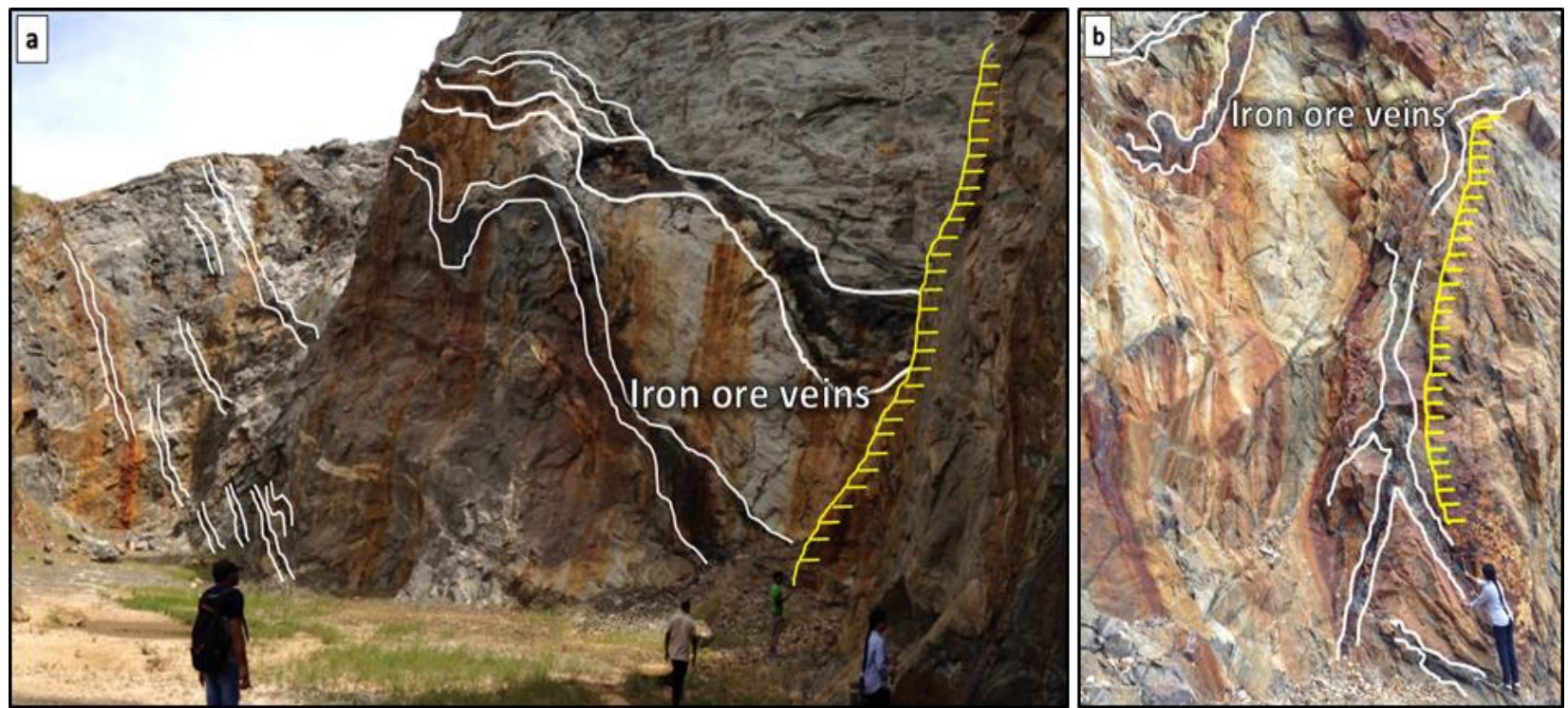

Fig. 2. Photographs showing the field relations of host rocks exposed at the quarry site: (a) Occurrences of iron ore veins on the surface of host rocks. (b) details of iron ore veins.

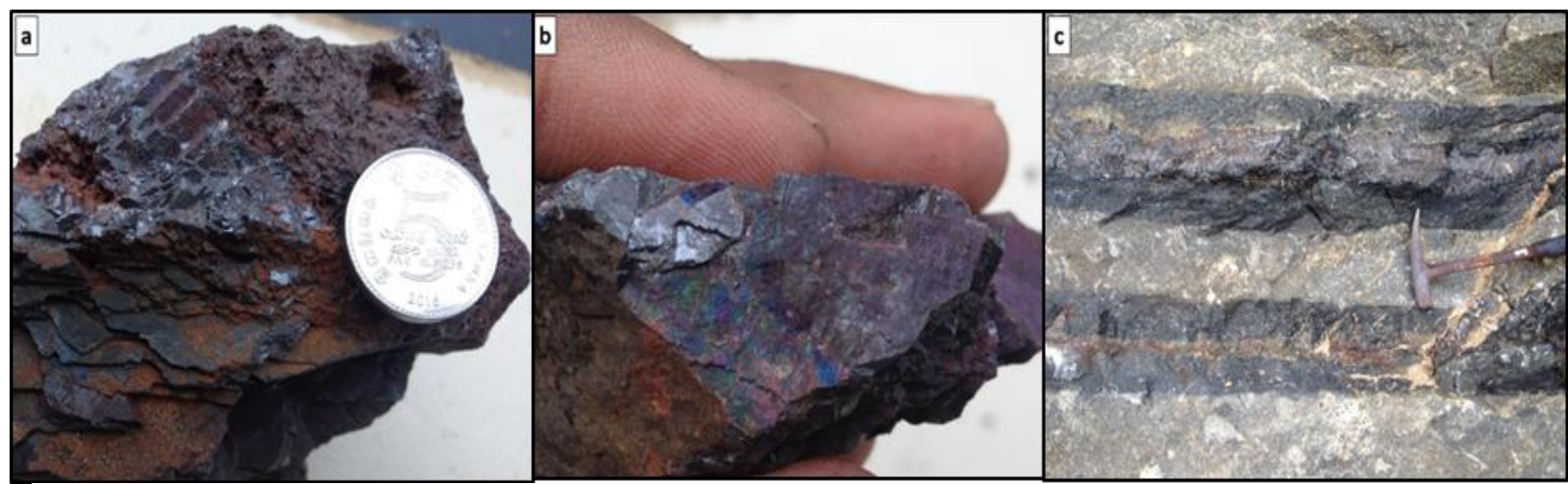

Fig. 3. (a) Developments of reddish colour as surface coatings (sample: BTM 11); (b) an iridescent formation on sample, BTM 13; (c) formation of iron ore veins at nearby host rock. 
and east slopes and flanks of the mountain. Presence of scattered ore bodies in northwestern part of the slope is relatively higher than the middle-western part of the mountain. At the bottom part of the western slope, weathered gravels of iron ores and quartz are found. Moreover, small gravels of iron ores with average sizes of $3 \mathrm{~cm}$ are scattered in a large area surrounding the mountain.

The host rocks, which are oriented in $\mathrm{N} 05^{\circ} \mathrm{W}$ direction are best exposed at the north-eastern slope, southern edge of the mountain and lower in the western slope (Figure 2). Mineralogically, the host rocks are garnet biotite gneisses with quartz, feldspar, biotite mica and garnet. On the exposed surfaces of the quarry site numbers of iron ore bearing veins, which are mostly concordant with the host rocks are observable (Figure 2). The core regions of veins composed mainly of magnetite and hematite with subordinate quartz (Figure 3c). However, at rim regions these veins show presence of mineralogically contrast black colour region between the magnetite vein and the host rock. Such occurrences indicate a reaction occurred during the iron ore vein formation. Presence of these iron ore bearing veins in nearby host rocks indicative for the existence of a major vein type mineralization (Nawaratne, 2009).

Unlike Panirendawa, where the magnetite deposit has formed at higher depths (Herath, 1995), the Buttala deposit occurs on the ground as a surface deposit. Also, it arises as a single deposit formation rather than scattered ones as hydrated ore deposits found in the south-west part of the country (Jayawardena, 1984; Fernando, 1986). Therefore, inexpensive open cast mining is possible to exploit the ore start from the top of the mountain. After confirming the main iron ore vein, underground mining can be employed. Deeper parts of the ore body can be mined by introducing mining methods such as cut-and-fill stoping, shrinkage stoping, sublevel open stoping, etc. (Hamrin et al., 2001).

Exposure of the iron ore deposit in a remote area would be advantageous in industrial scale mining. When establishing an industrial plant, it is necessary to concern many factors, such as topographical effects, land acquirement, construction cost, power, labor and housing, transportation cost, water supply, tailing disposal, environmental effects, etc. (Ohle, 1972; Comtois and Slack, 2016). The Buttala ore deposit area is topographically flat terrain with less disturbances for constructions and easy labor housing. Thus, the surrounding conditions are favorable for establishment of an iron and steel plant near to the ore deposit.

\section{MINERALOGY}

\section{Hand-Specimen Scale Mineral and Textural Characteristics}

Surface of most of the ore bodies are black in colour with metallic or sub-metallic luster and magnetically positive. Reddish coloured surface coatings in the outer-most layer of many of the ore exposures and cavities are frequent. These textures could be due to the chemical weathering of the ore body (Figure 3a). Furthermore, a few samples show iridescent formations on their surfaces (Figure 3b). Occasionally, hematite can have such kind of iridescent coatings similar to the interference colours of an oil slick. These species with thicker and brighter colourings are referred to as turgite, a compound probably represents a mixture of hematite or goethite or hematite with absorbed water (James, 1966).

\section{Detail Mineralogical Characteristics Based on the XRD}

The XRD analyses carried out for five powdered iron ore samples revealed that the magnetite $\left(\mathrm{Fe}_{3} \mathrm{O}_{4}\right)$ and hematite $\left(\mathrm{Fe}_{2} \mathrm{O}_{3}\right)$ are the main mineral constituents of the Buttala iron ore (Figure 4). In addition to that spinel $\left(\mathrm{MgAl}_{2} \mathrm{O}_{4}\right)$, ilmenite $\left(\mathrm{FeTiO}_{3}\right)$ and goethite $[\mathrm{FeO}(\mathrm{OH})]$ are detected as subordinate minerals (Figure 4). Three iron ore samples (BTM 1, BTM 4 and BTM 20) out of the analyzed five samples show clear peaks corresponding to the standard XRD pattern for magnetite. Other two samples viz; BTM 19 and BTM 21 show presence of hematite in addition to magnetite. Generally, all samples show minor peaks corresponding to spinel, ilmenite and goethite.

\section{GEOCHEMISTRY}

The geochemical results based on XRF analyses revealed that all analyzed ore samples (19 samples) contain high amount of $\mathrm{Fe}_{2} \mathrm{O}_{3}$. The $\mathrm{Fe}_{2} \mathrm{O}_{3}$ content is ranging from 62.2 to 89.5 wt. \% with an average value of 78.84 wt. \% (Table 1). This average Fe content of the Buttala ores, is higher than both the Panirendawa deposit (Kumarapeli, 1964; Kumara, 1982) and Seruwila deposit (Figure 5). Also Buttala shows 


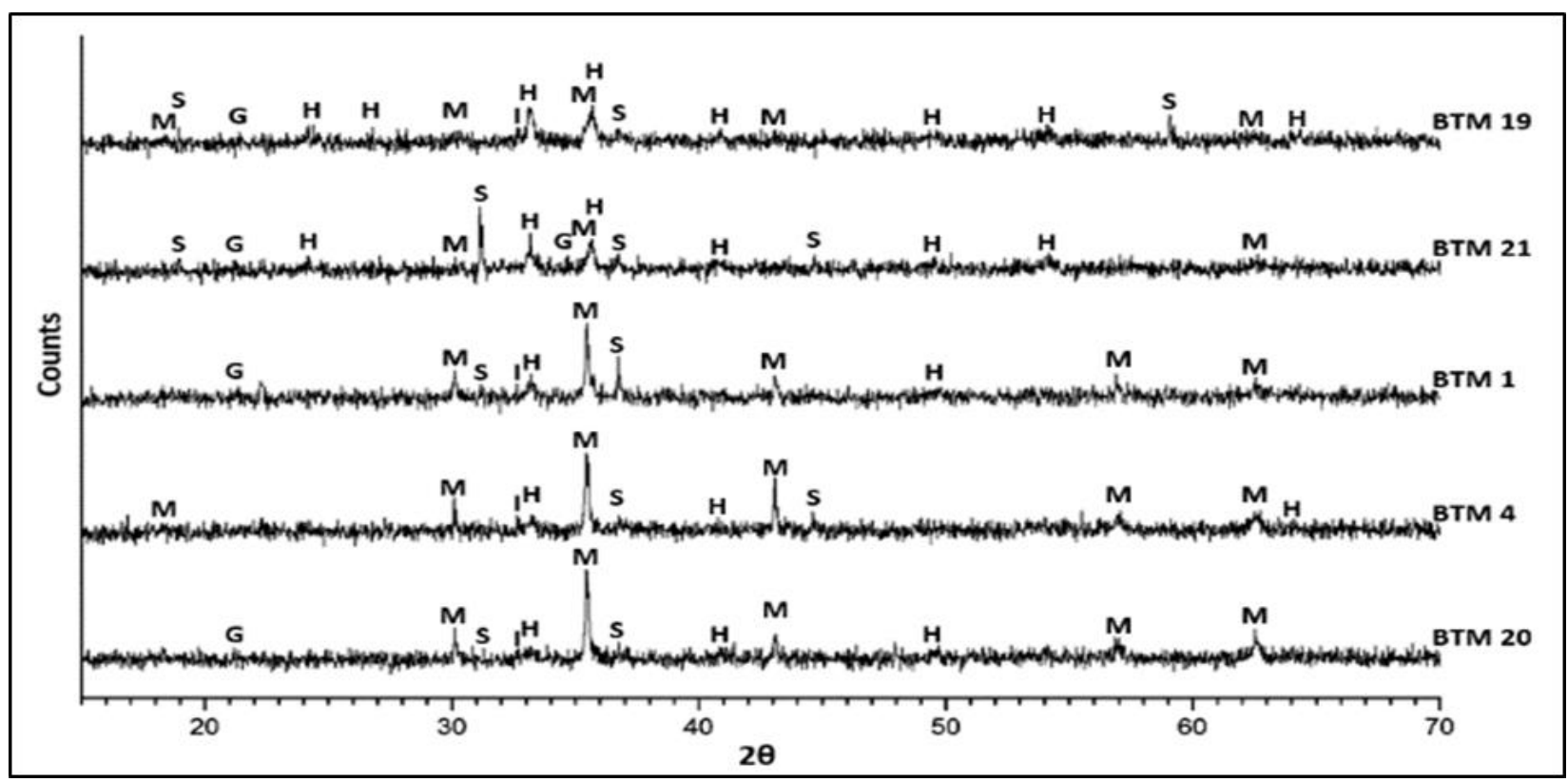

Fig. 4. The XRD pattern yielded for five iron ore samples (M-magnetite, H-hematite, S-spinel, Iilmenite, G-goethite).

higher Fe content than many of the hydrated iron oxide deposits Sri Lanka (Jayawardana et al., 2014). Furthermore, iron content of the Buttala ore represents higher ore grade value than many other ore clusters of super large iron deposits in world, such as; Ukraine, Russia, China, USA and Canada (Zhao et al., 2014).

Additionally, in these ore samples $\mathrm{Al}_{2} \mathrm{O}_{3}, \mathrm{SiO}_{2}$, $\mathrm{TiO}_{2}$ and $\mathrm{MgO}$ are detected as main gangue elements and each shows 7.54, 4.40, 3.60 and 2.54 wt. \% respectively (Table 1 and Figure 6). In the economic point of view, the high iron content, low gangue content and low deleterious element content is preferred (Singh et al., 2007). The alumina content of Buttala iron ore is higher than the other iron deposits in the country [Figure 5 (Kumarapeli, 1964; Jayawardana et al., 2014)]. Alumina is one of main impurities present in iron ores usually come from clay minerals such as kaolinite, montmorillonite, illite, alunite and gibbsite, and from laterite minerals (Singh and Mehrotra, 2007). High alumina content of iron ore is not favorable and significantly affects the efficient operation of blast furnaces (Singh et al, 2004). It causes increase in the viscosity of the slag and reacts with large quantity of fluxing materials, hence consume a large amount of fuel elevating the iron production cost (Indian bureau of mines, 1997; Sarkar et al., 2008). Therefore, beneficiation of aluminium before placing the feed material in blast furnace is important. Beneficiation techniques such as various flocculation methods, hydrocyclone and separation methods or removing processes of excess aluminium from iron ores can be applied (Rao and Narasimhan, 1985; Das et al., 1992; Singh et al, 2004; Singh and Mehrotra, 2007; Sarkar et al., 2008; Raghukumar et al., 2012). Therefore, the higher contents of alumina, in the Buttala ore deposit is tolerable in economic scale mining (Chun et al., 2015).

The amount of $\mathrm{SiO}_{2}$ is considerably lower in the Buttala ore than in the Panirendawa magnetite deposit as well as than several other hydrated iron ore deposits in the country (Figure 5). The silica mainly comes into the ore due to the accompany of quartz and silicate associated clay minerals. By employing usual floatation or magnetic separation methods, amount of silicate minerals can be reduced (Martins et al., 2017).

The high $\mathrm{TiO}_{2}$ content of the Buttala iron ore mostly indicates its association to the basic to intermediate meta-igneous rocks. Ion-titanium oxides such as titaniferous magnetite are being used in the world as a potential source of titanium (Samanta et al., 2013). However, higher amount of titanium increases the viscosity of slag and make difficulties in blast furnace process (Ohno \& Ross, 1963). Therefore, finding out an appropriate titanium separation method and the possibility to recover the titanium as a by-product from the ore can be recommended before any future commercial utilization of Buttala iron ore. 


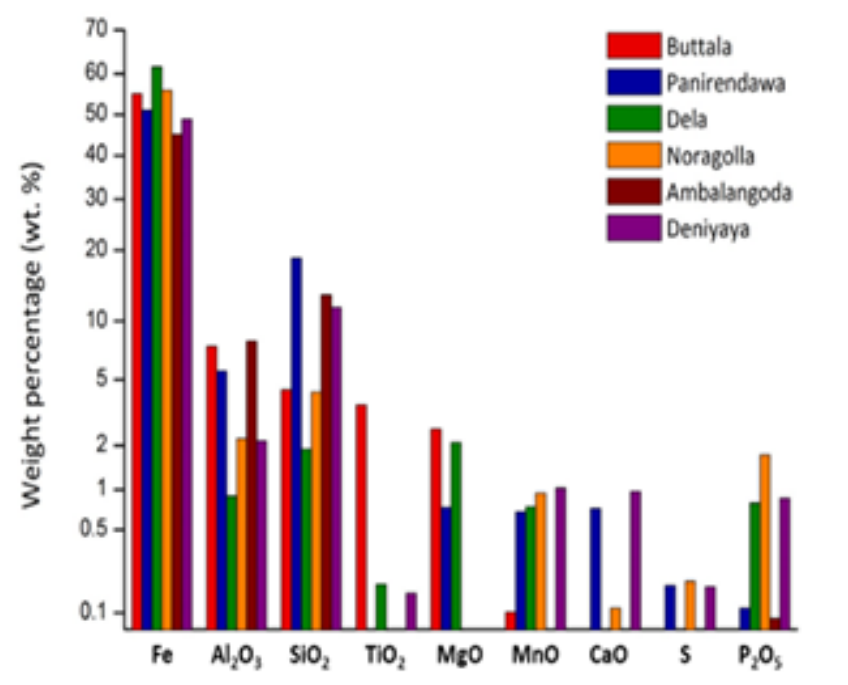

Fig. 5. The graph showing the comparison data of Buttala iron ore with other iron ores deposits in Sri Lanka (Kumarapeli, 1964 Kumara, 1982; Jayawardana et al., 2014).

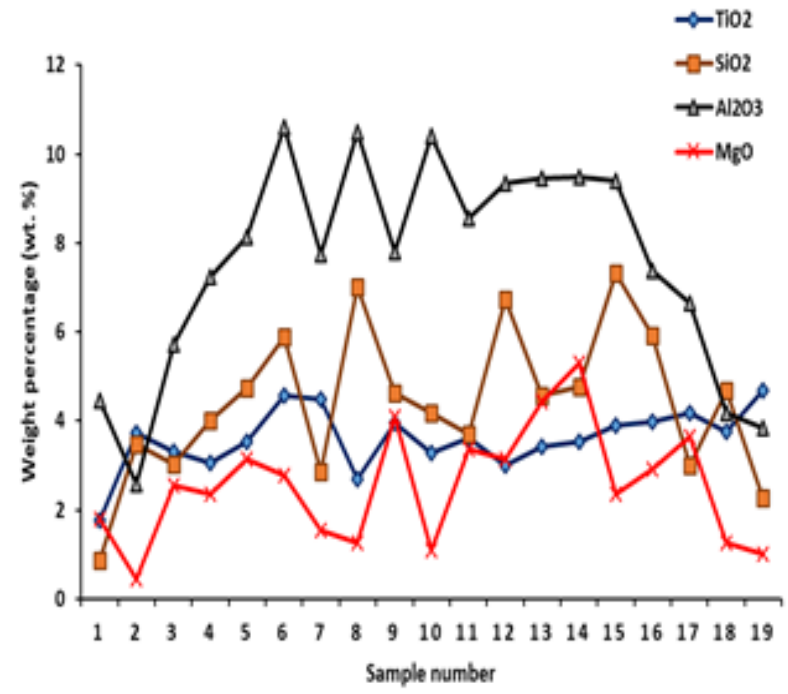

Fig. 6. A graph showing the main gangue distribution in each analyzed ore sample.
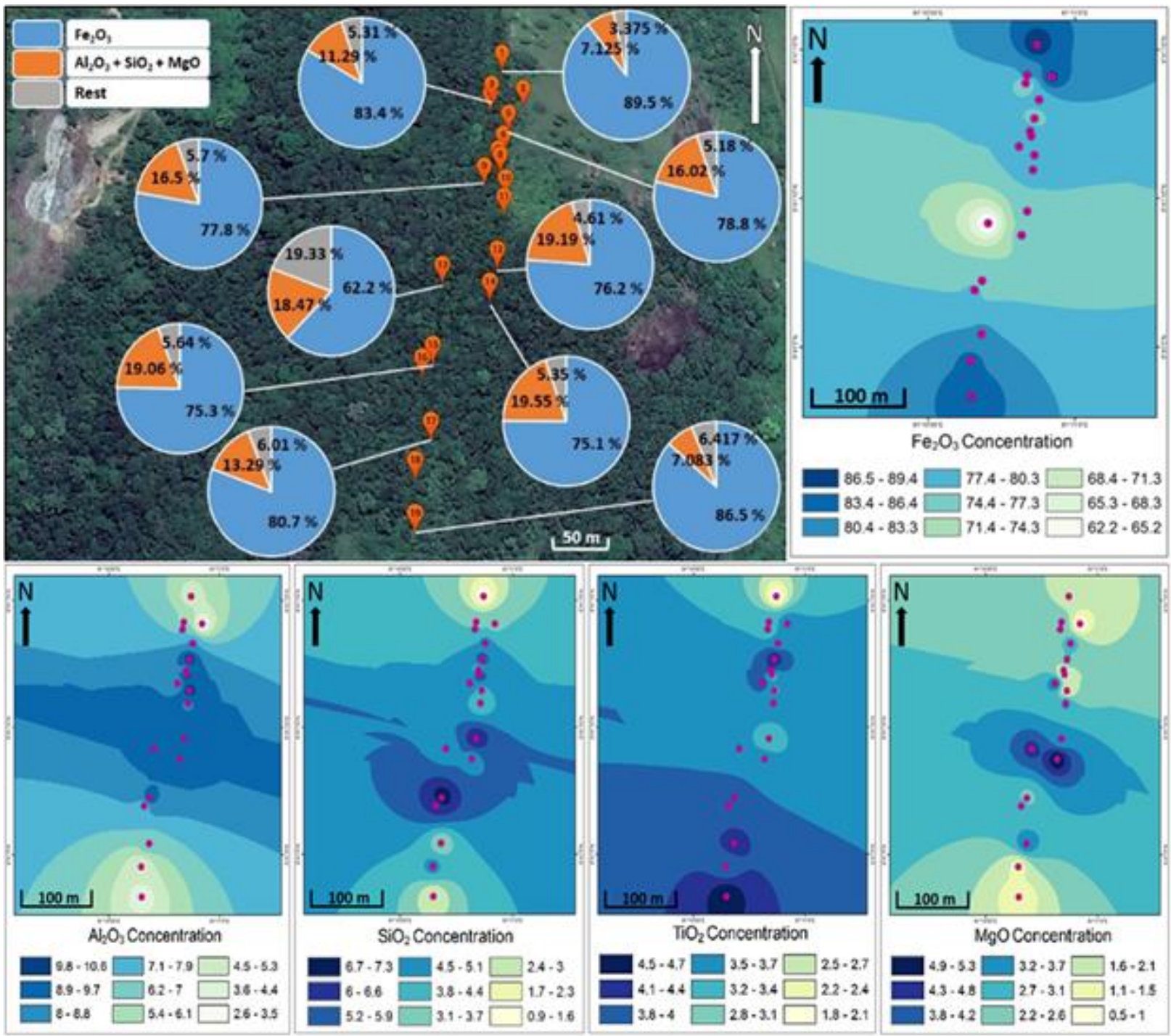

Fig. 7. Spatial distributions of $\mathrm{Fe}_{2} \mathrm{O}_{3}, \mathrm{Al}_{2} \mathrm{O}_{3}, \mathrm{SiO}_{2}, \mathrm{MgO}$ and $\mathrm{TiO}_{2}$ of the ore deposit. 
The presence of $\mathrm{MgO}, \mathrm{MnO}$ and $\mathrm{CaO}$ in Buttala iron ore is beneficial. The compound $\mathrm{MgO}$ is useful as a fluxing material and $\mathrm{MnO}$ as a sulphur removal constituent (Indian Bureau of Mines, 1997). Ions of $\mathrm{Mg}, \mathrm{Mn}$ and Ca may not be problematic unless they present in unusually large amounts (Dobbins and Burnet, 1982). As these constituents in Buttala ore are in lesser amounts no much issue to be considered. The amounts of sulphur and phosphorus, two elements making injurious effects on the properties of iron and steel (Reddy, 2007), in Buttala ore are negligible and hence no beneficiation practices are required.

Concentrations of $\mathrm{SO}_{3}$ and $\mathrm{P}_{2} \mathrm{O}_{5}$, which are considered as the main deleterious constituents of iron ores are in very lower values. Furthermore, the amounts of $\mathrm{MnO}, \mathrm{CaO}$ and other elements such as $\mathrm{Zr}, \mathrm{Co}, \mathrm{Zn}$, and Gd are very low indicating their lower abundance in the source rocks.

\section{SPATIAL CHEMICAL DISTRIBUTION}

The spatial distribution of the Buttala iron ore and maps for iron $\left(\mathrm{Fe}_{2} \mathrm{O}_{3}\right)$ and other four gangue elements $\left(\mathrm{Al}_{2} \mathrm{O}_{3}, \mathrm{SiO}_{2}, \mathrm{MgO}\right.$ and $\left.\mathrm{TiO}_{2}\right)$ obtained by the Quantum Geographic Information Software (QGIS) are shown in the Figure 7. Samples collected from both north and south part of the mountain showed higher iron content than its middle part of the mountain. Starting from north part of the ore containing mountain, the iron concentration gradually decreases upto the location no. 13. Then again the iron concentration gradually increases upto the most south part. As observed during the field, the ore body exposures along the ridge are also higher at its both north and south edges than the middle part. These observations are also comparable with the results of the magnetometer characterization study conducted for the Buttala ore deposit by Hewathilake et al. in 2013.

Table 1. Major and minor elemental composition of Buttala iron ore deposit.

\begin{tabular}{|c|c|c|c|c|c|c|c|c|c|c|c|c|c|c|}
\hline $\begin{array}{l}\text { Sample } \\
\text { (wt. } \\
\% \text { ) }\end{array}$ & $\mathrm{Fe}_{2} \mathrm{O}_{3}$ & $\mathrm{Al}_{2} \mathrm{O}_{3}$ & $\mathrm{SiO}_{2}$ & $\mathrm{TiO}_{2}$ & MgO & MnO & $\mathrm{CaO}$ & $\mathrm{Na}_{2} \mathrm{O}$ & $\mathrm{SO}_{3}$ & $\mathbf{P}_{2} \mathbf{O}_{5}$ & $\mathbf{Z r}$ & Co & Zn & Gd \\
\hline BTM 1 & 89.500 & 4.450 & 0.875 & 1.760 & 1.800 & 0.120 & 0.026 & ND & 0.020 & ND & 0.998 & ND & 0.209 & ND \\
\hline BTM 2 & 87.700 & 2.570 & 3.470 & 3.730 & 0.411 & 0.193 & 0.037 & ND & 0.099 & ND & 0.444 & 0.393 & 0.147 & 0.084 \\
\hline BTM 3 & 83.400 & 5.730 & 3.020 & 3.300 & 2.540 & 0.092 & 0.042 & ND & 0.024 & ND & 0.442 & 0.372 & 0.307 & 0.166 \\
\hline BTM 4 & 71.700 & 7.230 & 4.020 & 3.040 & 2.350 & 0.026 & 0.096 & 10.000 & 0.042 & 0.003 & 0.393 & 0.353 & 0.149 & 0.085 \\
\hline BTM 5 & 78.800 & 8.130 & 4.740 & 3.530 & 3.150 & 0.066 & 0.044 & ND & 0.116 & ND & 0.449 & 0.199 & 0.281 & 0.165 \\
\hline ВТM 6 & 74.400 & 10.600 & 5.880 & 4.580 & 2.780 & 0.107 & 0.069 & ND & 0.060 & ND & 0.421 & 0.188 & 0.253 & 0.142 \\
\hline ВТM 7 & 81.300 & 7.730 & 2.850 & 4.490 & 1.550 & 0.089 & 0.196 & ND & 0.046 & ND & 0.462 & 0.159 & 0.353 & 0.174 \\
\hline BTM 8 & 76.800 & 10.500 & 7.010 & 2.690 & 1.260 & 0.055 & 0.128 & ND & 0.073 & ND & 0.425 & 0.346 & 0.107 & 0.120 \\
\hline $\begin{array}{l}\text { BTM } 9 \\
\text { BTM }\end{array}$ & 77.800 & 7.800 & 4.620 & 3.940 & 4.080 & 0.139 & ND & ND & 0.045 & ND & 0.432 & 0.315 & 0.270 & 0.161 \\
\hline $\begin{array}{l}10 \\
\text { ВТM }\end{array}$ & 79.400 & 10.400 & 4.170 & 3.270 & 1.080 & 0.086 & 0.052 & ND & 0.094 & ND & 0.442 & 0.295 & 0.109 & 0.156 \\
\hline $\begin{array}{l}11 \\
\text { BTM }\end{array}$ & 79.200 & 8.560 & 3.710 & 3.620 & 3.370 & 0.095 & 0.034 & ND & 0.030 & ND & 0.432 & 0.182 & 0.282 & 0.149 \\
\hline $\begin{array}{l}12 \\
\text { BTM }\end{array}$ & 76.200 & 9.330 & 6.730 & 3.010 & 3.130 & 0.074 & 0.023 & ND & 0.019 & ND & 0.434 & 0.174 & 0.270 & 0.168 \\
\hline $\begin{array}{l}13 \\
\text { BTM }\end{array}$ & 62.200 & 9.460 & 4.580 & 3.430 & 4.430 & 0.087 & 0.023 & 14.300 & 0.026 & ND & 0.368 & 0.172 & 0.338 & 0.145 \\
\hline $\begin{array}{l}14 \\
\text { BTM }\end{array}$ & 75.100 & 9.490 & 4.760 & 3.530 & 5.300 & 0.068 & 0.014 & ND & 0.072 & ND & 0.406 & 0.162 & 0.290 & 0.151 \\
\hline $\begin{array}{l}15 \\
\text { BТM }\end{array}$ & 75.300 & 9.410 & 7.310 & 3.890 & 2.340 & 0.100 & 0.015 & ND & 0.061 & ND & 0.404 & 0.155 & 0.213 & 0.162 \\
\hline $\begin{array}{l}16 \\
\text { ВТM }\end{array}$ & 77.900 & 7.370 & 5.920 & 3.990 & 2.920 & 0.100 & 0.046 & ND & 0.080 & ND & 0.409 & 0.288 & 0.278 & 0.146 \\
\hline $\begin{array}{l}17 \\
\text { BTM }\end{array}$ & 80.700 & 6.640 & 3.010 & 4.180 & 3.640 & 0.135 & 0.018 & ND & 0.101 & ND & 0.449 & 0.181 & 0.271 & 0.162 \\
\hline $\begin{array}{l}18 \\
\text { BTM }\end{array}$ & 84.200 & 4.180 & 4.690 & 3.760 & 1.260 & 0.120 & 0.072 & ND & 0.057 & ND & 0.451 & 0.186 & 0.231 & 0.188 \\
\hline 19 & 86.500 & 3.830 & 2.260 & 4.690 & 0.993 & 0.191 & ND & $\mathrm{ND}$ & 0.034 & ND & 0.451 & 0.197 & 0.268 & 0.180 \\
\hline Avg. & 78.850 & 7.548 & 4.401 & 3.602 & 2.547 & 0.102 & 0.049 & 1.278 & 0.058 & $<0.001$ & 0.459 & 0.227 & 0.243 & 0.142 \\
\hline Min & 62.200 & 2.570 & 0.875 & 1.760 & 0.411 & 0.026 & ND & ND & 0.019 & ND & 0.368 & ND & 0.107 & ND \\
\hline Max & 89.500 & 10.600 & 7.310 & 4.690 & 5.300 & 0.193 & 0.196 & 14.300 & 0.116 & 0.003 & 0.998 & 0.393 & 0.353 & 0.188 \\
\hline SD & 6.225 & 2.421 & 1.673 & 0.699 & 1.298 & 0.042 & 0.048 & 3.897 & 0.030 & $<0.001$ & 0.133 & 0.099 & 0.071 & 0.044 \\
\hline
\end{tabular}


Contrast to the $\mathrm{Fe}_{2} \mathrm{O}_{3}$ distribution pattern, the contents of $\mathrm{Al}_{2} \mathrm{O}_{3}, \mathrm{SiO}_{2}$ and $\mathrm{MgO}$ are higher at the middle portion of the mountain ridge than the north and south edges. However, $\mathrm{TiO}_{2}$ contents of the ore bodies gradually increases towards the south direction.

\section{CONCLUSIONS}

Field relations of the Buttala iron ore deposit are favorable for economic scale mining practices and indicate the probable existence of a major vein type mineralization of iron ore. The ore body composed majorly of magnetite and hematite with subordinate spinel, ilmenite and goethite. The amount of $\mathrm{Fe}_{2} \mathrm{O}_{3}$ is averaged at 78.84 wt. \% representing its higher ore grade. The gangue constituents and deleterious impurities are in the acceptable values for favorable mining. Further extension of the ore deposit could be possible and additional investigations are needed to assess its approximate tonnage which would be advantageous for iron based industries in Sri Lanka.

\section{REFERENCES}

Amarasekara, H.M., Sajirupan, S., Senanayake, I.P., Sirisoma, R.H.A.N.C., Chaminda, S.P., Rohitha, L.P.S., Welideniya, H.S. and Abeysinghe, A.M.K.B., 2014. Designing suitable mining method and processing plant for Kukurampola magnetite ore body.

Beukes, N.J., Mukhopadhyay, J. and Gutzmer, J., 2008. Genesis of high-grade iron ores of the Archean Iron Ore Group around Noamundi, India. Economic Geology, 103(2): 365-386.

Brobst, D.A. and Pratt, W.P., 1973. United States mineral resources. pp.292, 296-298.

Christie, T. and Brathwaite, B., 1997. Mineral commodity report 15-Iron. NZ Min. pp.22-37.

Comtois, C. and Slack, B., 2016. Dynamic determinants in global iron ore supply chain. CIRRELT. pp.1-27.

Cooray, P.G., 1984. An introduction to geology of Sri Lanka (Ceylon). $2^{\text {nd }}$ revised ed. Colombo; National Museum Department. pp.81-83, 211212.

Das, B., Prakash, S., Mohapatra, B.K., Bhaumik, S.K. and Narasimhan, K.S., 1992. Beneficiation of iron ore slimes using hydrocyclone. Mineral and Metallurgical Processing, 9(2):101-103.

Dixon, C.J. ed., 2012. Atlas of economic mineral deposits. Springer Science \& Business Media. p.126.

Dobbins, M.S. and Burnet, G., 1982. Production of an iron ore concentrate from the iron-rich fraction of power plant fly ash. Resources and Conservation, 9:231-242.

Fernando, L.J.D., 1986. Mineral resources of Sri Lanka, Science education series: No 17. Natural Resources, Energy and Science Authority, Colombo. pp.51-62.

Hamrin, H., Hustrulid, W.A. and Bullock, R.L., 2001. Underground mining methods and applications. Underground mining methods: Engineering fundamentals and international case studies, pp.3-14.

Herath, M.M.J.W., 1995. Economic geology Sri Lanka: Fifth edition, Ministry of Industrial Development, Colombo. pp.60-70.

Hewathilake, H.P.T.S., Cooray, J.T. and De Silva, S.N., 2013. Magnetometer characterization of iron ore deposit in Buttala, Sri Lanka. Proceedings to 29th Technical Sessions of Geological Society of Sri Lanka. pp.17-20.

Indian bureau of mines, 1997. Monograph on iron ore (Revised ed.). Indian Bureau of Mines of Nagpur, Ministry of Mines, Government of India. pp.5-15.

James, H.L., 1966. Chemistry of the iron-rich sedimentary rocks. US Government Printing Office. pp. w2, 61.

Jayawardana, D.T., Balasooriya, N.W.B., Weerakoon, W.A.P., 2014. Geochemical characteristics of hydrated iron-ore deposit in Dela, Sri Lanka, Journal of Geological Society of Sri Lanka. (Vol. 16): 43-52.

Jayawardena, D., 1984. The present status of the development of mineral resources in Sri Lanka, Geological Survey Department. Journal of the National Science Council of Sri Lanka (Vol. 12): 62-63.

Jorgenson, J.D., 2010. Iron ore. Minerals year book: Metals and minerals (Vol. I). U.S. Government Printing Office. p.39.1.

Kabata-Pendias, A. and Mukherjee, A.B., 2007. Trace elements from soil to human. Springer Science \& Business Media. pp.210-211, 214.

Kanellopoulos, C., Valsami-Jones, E., Voudouris, P., Stouraiti, C., Moritz, R., Mavrogonatos, C. and Mitropoulos, P., 2018. A new occurrence of terrestrial native iron in the earth's surface: The Ilia thermogenic travertine case, Northwestern Euboea, Greece. Geosciences, 8(8), p.287.

Kennedy, B.A., 1990. Surface mining. Society for mining, metallurgy, and exploration (U.S.). pp.48, $57,60$.

Kumara, D.K.S., 1982. An evaluation of the behavior of pelletized Seruwila magnetite in direct reduction.

Kumarapeli, P.S., 1964. A report on the Panirendawa magnetite deposits in the Chilaw District. Ceylon Geological Survey Department, Colombo. pp.136.

Kutz, M., 2002. Handbook of materials selection. John Wiley \& Sons, New York. p 28.

Marion, J., 2012. Physical science in the modern world. Elsevier. p.117. 
Martins, P.F.F., Morais, C.A., Lameiras, F.S. and Albuquerque, R.O., 2017. Silica and iron recovery from a residue of iron ore flotation. Journal of Minerals and Materials Characterization and Engineering, 5(04):153.

Nawaratne, S.W., 2009. Feldspar and vein quartz mineralization in Sri Lanka: a possible post metamorphic mid-Paleozoic pegmatiticpneumatolitic activity. Journal of Geological Society of Sri Lanka 13, 83-96.

Ohle, E.L., 1972. Evaluation of iron ore deposits. Economic Geology, 67(7), pp.953-964.

Ohno, A. and Ross, H.U., 1963. Optimum slag composition for the blast-furnace smelting of titaniferous ores. Canadian Metallurgical Quarterly, 2(3): 259-279.

Pilchin, A.N., 2006. Iron and its unique role in earth evolution (Vol. 9). UNAM. p.5.

Raghukumar, C., Tripathy, S.K. and Mohanan, S., 2012. Beneficiation of Indian high alumina iron ore fines-a case study. International Journal of Mining Engineering and Mineral Processing, 1(2) :94-100.

Rao, K.H. and Narasimhan, K.S., 1985. Selective flocculation applied to Barsuan iron ore tailings. International Journal of Mineral Processing, 14(1): 67-75.

Reddy, L.K., 2007. Principles of engineering metallurgy. New Age International. p.38.

Roesler, M., 1921. The iron-ore resources of Europe (Vol. 706). Govt. Print. Off. p.12.

Samanta, S., Goswami, M.C., Baidya, T.K., Mukherjee, S. and Dey, R., 2013. Mineralogy and carbothermal reduction behaviour of vanadiumbearing titaniferous magnetite ore in eastern India. International Journal of Minerals, Metallurgy, and Materials, 20(10): 917-924.

Sarkar, B., Das, A., Roy, S. and Rai, S.K., 2008. In depth analysis of alumina removal from iron ore fines using teetered bed gravity separator. Mineral Processing and Extractive Metallurgy, 117(1):4855.

Senaratne, A., Dharmagunawardene, H.A., Fernando, W. A. R., 2001. Discovery of a new primary magnetite deposit in Wellawaya. Annual research sessions, University of Peradeniya, Sri Lanka (Vol. 6).

Singh, R., Bhattacharya, P., Bhattacharyya, K.K. and Maulik, S.C., 2004. Reduction of alumina in Indian iron ores. Metals Materials and Processes, 16(2-3): 1-14.

Singh, R., Mehrotra, S. P. (2007). Iron ore resources and beneficiation practices. Chapter 1. pp.1-16.

Silver, J. ed., 1993. Chemistry of iron. Glasgow, UK: Blackie Academic \& Professional. pp.2-4.

Spier, C.A., de Oliveira, S.M.B., Rosière, C.A. and Ardisson, J.D., 2008. Mineralogy and traceelement geochemistry of the high-grade iron ores of the Águas Claras mine and comparison with the Capão Xavier and Tamanduá iron ore deposits, Quadrilátero Ferrífero, Brazil. Mineralium Deposita, 43(2), pp.229-254.
Summerfield, D., 2016. Australian resources review: Iron. Geoscience Australia, Canberra, Australia.

U.S. Geological Survey, 2018. Mineral commodity summaries 2018: U.S. Geological Survey. p.89.

Volborth, A., 2012. Elemental analysis in geochemistry (Vol. 8):78-79.

Yellishetty, M., Mudd, G.M., 2014. Substance flow analysis of steel and long term sustainability of iron ore resources in Australia, Brazil, China and India. Journal of cleaner production, 84:400-410.

Yellishetty, M., Ranjith, P.G. and Tharumarajah, A., 2010. Iron ore and steel production trends and material flows in the world: Is this really sustainable? Resources, conservation and recycling, 54(12):1084-1094.

Zhao, Y., Feng, c. and Li, D., 2014. The major ore clusters of super-large iron deposits in the world, present situation of iron resources in China, and prospect. Acta geologica sinica-english edition, 88(6):1895-1915. 
